\title{
PROSPECTS FOR JUSTICE AND STABILITY IN BURMA
}

\author{
Stephen McCarthy
}

\section{Abstract}

The prospects for improving justice and stability in Burma remain bleak. Conventions and talks have proven to be neither fully representative nor substantive while economic prospects remain woeful, consolidating purges continue, and institutional reforms are being undermined by mistrust and the ruling generals' unwillingness to relinquish power.

Keywords: Burma, justice, stability, trust, power

Overturning military rule in Burma would be a daunting and problematic exercise on many political, social, and moral fronts. The ruling regime of the Tatmadaw (army) has situated the country within the Association of Southeast Asian Nations (ASEAN), whose member states are responsive in some measure to international pressure. Within that context, preservation of the regime in principle should require a transition from brutish tyranny to a less brutish form. One might hope that this ideal could at least moderate despotic behavior. Yet, it is evident from the generals' failed attempts at dialogue with the political opposition, their convening of hollow constitutional conventions, and their public displays of benevolent concern and Buddhist piety in recent years that they have not moderated their despotism. Indeed, no evidence exists to suggest that the generals wish to transform their regime into anything other than a longer lasting form of tyranny. Rather, they have taken every step to safeguard their power - apparently the only presupposition underlying many of their activities. By granting the occasional concession to placate

Stephen McCarthy received his Ph.D. in Political Science at Northern Illinois University. He is a Research Fellow in the Griffith Asia Institute at Griffith University, Brisbane, Australia. The author wishes to thank an anonymous reviewer for constructive comments and suggestions.

Asian Survey, Vol. 46, Issue 3, pp. 417-436, ISSN 0004-4687, electronic ISSN 1533-838X. (C) 2006 by The Regents of the University of California. All rights reserved. Please direct all requests for permission to photocopy or reproduce article content through the University of California Press's Rights and Permissions website, at http://www.ucpress.edu/journals/rights.htm. 
the international community, they occasionally have been rewarded with some international funding.

Political stability is important for the lasting preservation of any regime. Stability may be maintained by imposing order and resisting change or it may be improved by rulers who move the regime in just directions. Although political stability should set the parameters within which any regime's natural decay may be prevented by improvements in justice, the Tatmadaw's ruling junta is an example of an imposed rather than a just order. "Stability of the State," led by the State Peace and Development Council (SPDC), ${ }^{1}$ is cited as one of the regime's four political objectives, which are published daily on the front page of its newspaper, the New Light of Myanmar. Yet, the Tatmadaw's version of stability and order is inherently unstable, not only because its approach lacks political legitimacy but also because - while setting out to oppose the kind of individual freedoms fostered by Western liberalism - it effectively secures the rule of incumbents against any political change at all. What is required to improve justice and promote lasting stability in the current regime is more than the granting of minor concessions for short-term gains. The problems facing the generals are complex and no doubt would also cause strife for the opposition National League for Democracy (NLD) if it ever were to gain power. Burma is not a small polis but the second largest country in Southeast Asia and a republic composed of many ethnic minorities. Nevertheless, if preserving its regime implies improving its stability through justice, it is appropriate to question how, if at all, this could be undertaken given the current political circumstances.

\section{Conventions and Talks}

Because all political regimes comprise varying degrees of democratic and oligarchic elements, it would seem that the best way to preserve a regime is to ensure that these elements are properly mixed. This implies that all citizens must, to some degree, take part in politics or at least that the people voluntarily confirm their political arrangements. In Burma, this requires that the ruling oligarchs - the Tatmadaw - share their political power with the democratic elements, largely represented by the NLD and ethnic minority groups. Preservation also demands that a proper, fully representative convention on a new constitution be initiated with at least the possibility of all parties voluntarily acquiescing in its arrangement. Yet, the reluctance on the part of the democratic opposition to attend any such convention is understandable.

General elections were held in Burma in 1990, with the NLD winning 392 of the 485 seats available- $80.8 \%$ of the total seats and $59.9 \%$ of the popular

1. The ruling junta changed its name from the State Law and Order Restoration Council (SLORC) to the SPDC in November 1997. 
vote. ${ }^{2}$ The Tatmadaw's party could only muster 10 seats or $2.1 \%$ of the total and $21.2 \%$ of the popular vote. Refusing to hand over power, the generals explained that the election was merely a signal for constitutional change and that all major parties, or at least those with members not still incarcerated, would be invited to attend a convention designed for that purpose. The NLD walked out of, and were later expelled from, the national convention in 1995, and in 1996 the SLORC passed Law 5/96, silencing any criticism of the convention and the Constitution. Prior to 2004, the national convention had not convened in seven years. It had become obvious to all, including the generals, that the first step toward power sharing would be a meaningful dialogue among the SPDC, NLD, and ethnic minorities. The NLD, however, along with some minority groups, chose to boycott the constitutional convention in 2004, citing the continued detention of Aung San Suu Kyi and the party's deputy chairman, Tin Oo. National constitutional conventions provide the generals with a means to placate international pressure by appearing to facilitate the democratic process. Yet, the generals' intentions and conduct, and indeed the history of the convention itself, all highlight the Tatmadaw's conception of stability as meaning preservation of order and the status quo rather than improving justice in the regime itself.

Concessions made when the rulers are pressured by international bodies also have not translated into any real improvements in domestic justice. In October 2001, the SPDC and then Secretary-1 General Khin Nyunt entered into secret talks with Aung San Suu Kyi that were brokered by then United Nations Special Envoy for Burma Rizali Ismail. Their talks remained secret, and the content was not published. Unless they produce tangible commitments for change, such talks - indeed, any future dialogues - may simply constitute yet another attempt by the Tatmadaw to placate international concerns in return for shortterm gains. The signs have not been promising: during the 2001 talks, the Thai government reported that power-sharing deals were being brokered, noting that Khin Nyunt and Suu Kyi met for discussions every two weeks. The NLD, on the other hand, denied the existence of any such deals, claimed that the two were not meeting regularly, and said that the talks had not progressed beyond confidence building. ${ }^{3}$ Indeed, although some generals have appeared to be more pragmatic than others, the hardliners in charge, and especially Senior General Than Shwe, may see to it that the talks never do. Khin Nyunt's sacking from the prime ministership in October 2004 raises serious questions as to the future of the ceasefire agreements brokered under his watch with ethnic insurgents and also of any meaningful future dialogue with Aung San Suu Kyi.

2. Donald Seekins, The Disorder in Order: The Army-State in Burma since 1962 (Bangkok: White Lotus Press, 2002), p. 210.

3. See "NLD Vice Chairman, U Tin Oo in Response to Thailand's Defense Minister, Chavalit," Irrawaddy, September 17, 2001. 
Suu Kyi has said that a dialogue requires confidence on both sides, which requires trust, and that with trust, truth and reconciliation naturally follow. ${ }^{4}$ Part of this confidence building is tied to her insistence that all political prisoners be released. Various reports and records place the number of political prisoners in Burma at between 1,300 and 1,400, the majority of whom are NLD members or supporters. ${ }^{5}$ Although the release of some of these prisoners by the SPDC over the past several years ${ }^{6}$ in the junta's eyes demonstrates good faith and progress, officials continue to retain and add to a substantial inventory of prisoners with which to bargain in the foreseeable future. As another sign of good faith, the SPDC in the past has permitted the reopening of NLD offices, although political activities and meetings inside them were still prohibited and the use of telephones and faxes banned. Public meetings of more than five persons still require a permit from the authorities.

Following several visits to Burma by Ismail, the Tatmadaw in May 2002 released Aung San Suu Kyi from a 19-month period of house arrest that began when she attempted to travel outside of Rangoon to meet supporters in September 2000. Four days after Suu Kyi was released, Japan announced that it would resume its official development assistance (ODA) to Burma, which had been withdrawn following the 1988 coup. Although Japan had previously resumed providing some \$6 million in "humanitarian aid" per year to Burma along with any ODA funds committed before the coup, Tokyo now offered to contribute $\$ 5$ million toward construction of a power plant in Rangoon, \$28 million toward a power plant in the Kayah State - classified as humanitarian aid - and \$7 million for medical equipment. In July 2002, Japan announced it would contribute more aid to improve Burma's information technology sector. ${ }^{7}$ This aid could be construed as a reward to the SPDC for releasing Suu Kyi for the second time and for continuing the talks. That same month South Korea signed an agreement to provide financial and technical assistance toward

4. Aung San Suu Kyi, The Voice of Hope: Conversations with Alan Clements (New York: Seven Stories Press, 1997), p. 39.

5. See Amnesty International, Myanmar: The Administration of Justice-Grave and Abiding Concerns, April 1, 2004, report, available online at $<$ http://web.amnesty.org/library/Index/ ENGASA160012004?open\&of=ENG-MMR $>$; and the Assistance Association for Political Prisoners (AAPP), Mae Sot, Thailand. Data are available online at $<\mathrm{http}: / / \mathrm{www}$.aappb.net/data. html>.

6. In November 2004, over 30 political prisoners were released from prisons in Rangoon, Mandalay, and western Burma, including several senior NLD members along with the 1988 prodemocracy protests' student leader Min Ko Naing, as part of a "good cop" move that hopes to distance the junta from Khin Nyunt's disbanded National Intelligence Bureau. The release was part of 9,000 prisoners to be freed, announced in the weeks leading up to an ASEAN summit in Laos.

7. See Far Eastern Economic Review, May 4-10, 2001; Allen Clark, "Burma in 2002: A Year of Transition," Asian Survey 43:1 (January/February 2003), pp. 127-34, esp. p. 132; and Reuters, May 13, 2002. 
developing Burma's mobile phone capabilities. ${ }^{8}$ With the peasant poor comprising the overwhelming majority of Burma's population, one might reasonably question what improvements in their justice could arise from improving the country's mobile phone capabilities.

Along with members of her entourage, Suu Kyi was arrested again in May 2003 while visiting her supporters in northern Burma, after serious clashes between the supporters and members of the regime's mass organization, the Union Solidarity and Development Association (USDA). NLD offices were shut and up to 200 members arrested, along with at least 300 NLD supporters across Burma. ${ }^{9}$ At the moment, only the party's headquarters in Rangoon remains open, and it is monitored by the authorities, though some regional "offices" have been reopened at the homes of NLD officials. The arrests followed Suu Kyi's criticism of the Tatmadaw for refusing to start serious talks. ${ }^{10}$ Although 91 people who were detained at the same time as Suu Kyi were released in July 2003, the Tatmadaw's failure to release Suu Kyi attracted worldwide criticism, including from the United Nations, Japan, the United States, and the European Union (EU). The previous month at its annual foreign ministers' meeting ASEAN issued an unprecedented joint statement calling for her release. ${ }^{11}$ General Than Shwe responded by dispatching his foreign minister and deputy foreign minister to Thailand, Japan, Malaysia, Indonesia, Singapore, China, Bangladesh, Pakistan, and India with a personal letter claiming that Suu Kyi and the NLD had been plotting an uprising and that the opposition leader was encouraging armed ethnic rebel groups to take part. ${ }^{12}$

Britain nonetheless persuaded the EU to toughen sanctions against Burma, issuing a travel ban on the country's leaders and their families, freezing the assets of 150 senior officials, and tightening the arms embargo. Japan again froze its financial aid, and the U.S. Congress passed the Burmese Freedom and Democracy Act. This measure, which went into effect that August, banned specified Burmese imports, froze the country's meager financial assets in American

8. Xinhua News Agency, July 9, 2002.

9. BBC, "Burma Moves to Stifle Protest," BBC NEWS, June 2, 2003, available online at $<$ http://news.bbc.co.uk/go/pr/fr/-/2/hi/asia-pacific/2955410.stm >; and BBC, "Protests Mark Burma Anniversary," ibid., August 8, 2003, available online at <http://news.bbc.co.uk/go/pr/fr/-/1/hi/ world/asia-pacific/3134123.stm>.

10. BBC, "Burma's Suu Kyi Attacks Junta," ibid., April 23, 2003, available online at < http:// news.bbc.co.uk/go/pr/fr/-/1/hi/world/asia-pacific/2969327.stm > . Currently, Suu Kyi remains under house arrest in Rangoon; her latest 12-month detention extension order was delivered in November 2005. Her phone line has been cut, and she is allowed only the occasional visit from her doctor.

11. ASEAN, Joint Communique of the 36th ASEAN Ministerial Meeting, Phnom Penh (June 16-17, 2003), Clause 18, available online at <http://www.aseansec.org/14833.htm>.

12. BBC, "Burma Defends Suu Kyi Custody," BBC NEWS, July 13, 2003, available online at $<$ http://news.bbc.co.uk/go/pr/fr/-/2/hi/asia-pacific/3062655.stm >. 
banks, and placed further visa restrictions on Burmese officials attempting to enter the U.S.

\section{Economic Reform and International Pressure for Democratization}

Burma's economic prospects will continue to remain poor so long as the SPDC offers only minor acts of good faith in return for international funding. Meanwhile, China has increasingly contributed to the country's infrastructure development. If ASEAN wished to pressure Burma to resist Chinese aid and growing strategic influence in the region, funding for this type of development would have to be sought elsewhere. ${ }^{13}$ This would seem unlikely given that at the summit held in Vientiane in November 2004 ASEAN member states pushed ahead with proposals to incorporate China into a massive East Asian Free Trade Zone. Recent ASEAN summits have regularly included China, Japan, and South Korea (i.e., ASEAN + 3), and in December 2005 Australia, New Zealand, and India joined ASEAN's East Asian Summit. The Chinese government not only criticizes foreign interference in Rangoon's internal affairs, including the use of sanctions, but hosts visits by Burma's military leaders and promotes further cooperation between the People's Liberation Army and the Tatmadaw. ${ }^{14}$ Russia has also offered some infrastructure aid to Burma, although its announcement in May 2002 that it will contribute $\$ 150$ million to build a center for nuclear studies - including construction of a research nuclear reactor, laboratories, and support infrastructure - may eventually cause Burma more trouble than good. In the years since 2001, when Burma signed a deal with the Russian Ministry of Atomic Energy to build a 10-megawatt nuclear test reactor, the foundation for the reactor has been laid and hundreds of personnel have been sent to Russia for nuclear technology training. The project stalled, however, when Burma was unable to continue financing the facility's construction. In April 2006, SPDC Vice Chairman Vice Senior General Maung Aye revived the project by signing a new cooperation agreement with the Kurchatov nuclear research center. ${ }^{15}$

13. China is assisting Burma in building three hydropower plants and its third international airfield, Hanthawady International Airport, in the Bago division. Mandalay airfield is now Southeast Asia's longest runway and capable of handling military transports. China helped fund its construction and also funded the building of a deep sea port at Tilowa - facing the Indian Ocean - that may be capable of handling Chinese nuclear submarines in the future, along with a highway connecting the port to Yunnan Province.

14. Prime Minister General Soe Win traveled to Beijing in February 2006 to secure China's future veto of any United Nations attempts to impose economic and political sanctions on Burma via the Security Council. In April 2006, SPDC Vice Chairman Vice Senior General Maung Aye, accompanied by Foreign Minister General Nyan Win, traveled to Moscow to seek the same assurances from Russia.

15. Sergei Blagov, "From Myanmar to Russia with Love," Asia Times Online, April 12, 2006, $<$ http://www.atimes.com/atimes/Southeast_Asia/HD12Ae01.html >. 
In the meantime, however, without the major international aid that has been denied to Burma by the International Monetary Fund (IMF) and the World Bank, the Burmese currency, the kyat, will remain overvalued and runaway inflation will prevent any improvement in the country's foreign debt. ${ }^{16}$ Domestic private enterprise in Burma has been strangled and forced to revert to the black market, whose trade may be preventing a total financial collapse. Despite the effects of the Burmese Freedom and Democracy Act and similar threats of further sanctions by the EU following the 2003 arrest of Aung San Suu Kyi, Western trade sanctions remain measures that are effective symbolically and relatively ineffective politically. Although the U.S. import ban forced the generals to switch to euros as the currency for all importing and exporting business - creating a fourth tradable currency and further financial headaches for Burma - exports to the U.S., mainly textiles, were estimated to be worth only around $\$ 400$ million per year in $2003 .{ }^{17}$ Despite the loss of jobs that forced many textile workers into poverty or prostitution, the generals have proved adept at adapting to external isolationist policies and, indeed, for much of their history have welcomed them. For the junta, economic liberalization was only a relatively new experiment - primarily a means to gain foreign currencythat could be withdrawn if it threatened their political stability. Hence, it has been hard for them to conceive of sanctions as being punitive measures designed to instigate political reform. Burma maintains alternative trade markets in China and India; it is seeking trade and investment opportunities with Russia; its 1997 admission into ASEAN effectively secured its markets in Southeast Asia, particularly in Singapore and Thailand; and it stands to benefit indirectly from the new ASEAN-China trade accord.

16. Although the local Burmese currency is the kyat, business is also conducted using foreign exchange certificates (FECs), along the lines of a similar second currency formerly adopted by the PRC. Before the United States imposed a ban on Burmese imports in August 2003, U.S. dollars were readily accepted for most trade, their use being either discouraged or encouraged depending upon the government's concern for inflation or attracting foreign investment. The black market traded in all three forms of currency, including FECs, which were devalued by the authorities in 2001 from a 1:1 peg to the U.S. dollar, thus creating a tradable third currency in Burma. In August 2003, the Burmese leadership instructed all government organizations and private business to use euros for importing and exporting goods. While the official exchange rate was six kyat to one dollar, the kyat on the black market fell to its then lowest level in May 2002, trading at K 1,200:\$1, rising to K 820:\$1 after Suu Kyi's release, then falling again to K 1,060:\$1 by the end of August 2002. By late 2002, it was K 900:\$1 and in August 2003, following the announcement of a U.S. ban on Burmese imports, fell to K 1,100 as dealers sought the greenback, then settled to K 1,030. By October 2003, the kyat was again trading at 910:\$1. In late 2002, Burma's inflation rate was approximately $35 \%$; it was expected to reach approximately $37.5 \%$ in 2005 (see the IMF, World Economic Outlook, 2004).

17. BBC, "Mixed Feelings over Burma Sanctions," BBC NEWS, July 16, 2003, available online at $<$ http://news.bbc.co.uk/go/pr/fr/-/1/hi/world/asia-pacific/3073053.stm $>$. 
The generals' foreign direct investment strategies of the 1990s proved to be as expedient as their choice in trading partners. There was no evidence to suggest that long-term economic planning guided the approval of projects by the state-run Myanmar Investment Corporation (MIC), nor was there any evidence of foreign investment monies being distributed among the Burmese people. On the contrary, the Tatmadaw's company, Union of Myanmar Economic Holdings (UMEH), whose finances are not publicly reported, operates an immense slush fund for various endeavors. ${ }^{18}$ Meanwhile, the SPDC blames foreigners for its economic woes, ${ }^{19}$ continues to maintain faith in its own economic stewardship, and only occasionally replaces errant generals on the grounds of mismanagement. ${ }^{20}$

Despite the Tatmadaw's public displays of anti-corruption rhetoric, perhaps its most reliable source of unreported income continues to be the drug tax. To placate Western criticism over the lack of action taken against drug warlords, the generals have shown themselves to be attacking the problem by closing down warlords for the world's press and opening a new anti-drug museum, while continuing to refine their lucrative connections and trade in methamphetamines. ${ }^{21}$ Because of rising discontent in Thailand toward drug dealers, the Thai government in 2003 ordered police to clamp down on dealers of Burmese origin selling amphetamines and methamphetamines; many dealers were arrested or killed. Despite public efforts to curb production, however, opium remains a viable alternative for ethnic insurgent groups who have signed ceasefires with the government, if demand should fall in the methamphetamine market or rise in the heroin market. The booming trade in methamphetamines would seem to tarnish the allegedly successful eradication efforts of the SPDC, measured in terms of falling opium poppy cultivation, as reported by the United Nations Office on Crime and Drugs (UNOCD). ${ }^{22}$ In early 2003, Burma failed

18. Mary Callahan, "Burma: Soldiers as State Builders," in Coercion and Governance: The Declining Role of the Military in Asia, Muthiah Alagappa, ed. (Stanford: Stanford University Press, 2001), p. 426.

19. For example, the SPDC seemed to concur with the former Malaysian Prime Minister Dr. Mahathir's claims that Asia's financial crisis was instigated by philanthropist George Soros as a conspiracy to topple Asian currencies (see New Light of Myanmar, November 11, 1997).

20. The two generals responsible for overseeing foreign investment approvals - then secretary3 and the former head of UMEH, Win Myint, and then deputy prime minister and head of the MIC, Tin Hla-were sacked for corruption in a purge of seven senior generals in late 2001.

21. Desmond Ball, Burma and Drugs: The Regime's Complicity in the Global Drug Trade, Working Paper, no. 336 (Canberra: Strategic and Defense Studies Center, Australian National University, 1999).

22. The UNOCD's annual Opium Survey is carried out under the supervision and implementation of the Myanmar Central Committee for Drug Abuse Control (CCDAC). The survey states that it "was not designed to monitor or validate the results of the eradication campaigns carried out by the Myanmar Government." See UNOCD, Myanmar Opium Survey 2005 (New York: United 
to be certified by the U.S. State Department as being in compliance with antinarcotics regulations, despite strong lobbying on Rangoon's behalf by the Washington-based public relations firm DCI Group.

In theory, it is important for a regime to respect the wishes of the middle class because the latter is capable of overturning the ruling body in both democracies and oligarchies. ${ }^{23}$ The middle class in Burma comprises military officers and Chinese business people, all of whom stand to gain from maintaining the status quo. The SPDC clearly does not neglect the bulk of the regime's middle class; the junta has created an "exclusive social order of privilege" with welfare, health, and educational facilities for active and retired officers and soldiers. ${ }^{24}$ Regional commanders have amassed great wealth through narcotics and other black-market trade. Burma's ASEAN neighbors have used the "constructive engagement" argument to justify any investment as being in the interests of promoting democracy and human rights through economic development and the growth of a middle class. However, this argument seems to be hollow in the case of Burma. Suu Kyi condemns foreign investment in Burma because it only enriches an already wealthy elite bent on monopolizing economic and political power. ${ }^{25}$ Although she has stated that her release in 2002 along with other members of the NLD did not change her attitude toward sanctions, she is receptive to certain social development work and humanitarian aid projects directed toward the poor and disadvantaged. ${ }^{26}$ Suu Kyi believes that a true policy of engagement should mean that countries engage the democratic forces as well as the Tatmadaw.

Much faith was placed in the possible ramifications of Khin Nyunt's "roadmap to democracy" announced in a speech delivered soon after he became prime minister in August 2003. Some saw this as a timely opening for the U.S. to re-engage Burma by reversing its sanctions policy. ${ }^{27}$ Arguments can be

Nations, 2005), p. 37. The UNOCD claims that opium poppy cultivation in Myanmar has decreased by $75 \%$ since 1998 . The survey is undertaken using a combination of satellite remote sensing and field surveys of sample villages randomly selected from a database of villages provided by the Myanmar Forest Department. The results are then extrapolated to the entire country using area estimation formulas. This methodology produces a national estimate that is open to criticism.

23. Carnes Lord, trans., Aristotle, The Politics (Chicago: University of Chicago Press, 1984), pp. 1309b18-34.

24. See Callahan, "Burma," p. 424; and Andrew Selth, Burma's Armed Forces: Power without Glory (Norwalk: EastBridge, 2002), pp. 259-68.

25. Aung San Suu Kyi, "Commencement Address Delivered on Her Behalf by Dr. Michael Aris at the American University upon Receiving Honorary Doctor of Laws Degree," Washington D.C., January 26, 1997, at <http://www.freeburmacoalition.org/frames/Suu\%20Kyi/suukyiau. $\mathrm{htm}>$.

26. Clark, "Burma in 2002," p. 129.

27. NBR Analysis, Reconciling Burma/Myanmar: Essays on U.S. Relations with Burma, John Badgley, ed. (Seattle: National Bureau of Asian Research, 2004). 
offered on both sides of the sanctions debate: though morally symbolic, sanctions have not achieved their desired political effect. To date there has been little to no indication of any realistic movement toward democratic structural change, via a "roadmap" or otherwise. It may be too early to seize upon further announcements by the new cabinet to indicate any "tectonic shift" on the part of the SPDC, given the distance it has placed between itself and Khin Nyunt. A far more cogent moral imperative is the humanitarian crisis facing the country, which justifies the provision of humanitarian aid. It is unclear what immediate effects the lifting of sanctions would have on the Burmese economy or even whether many Western investors would be clamoring to return: the success achieved by pro-democracy activists was not the only reason foreign investors pulled out of Burma in the 1990s. ${ }^{28}$ It has been argued that returning to the so-called "two hands" policy or "carrot and stick" approach may be possible if the removal of sanctions, most particularly against infrastructure aid, is indeed wished for by the regime. While it would seem that this method-which lies between the extremes of isolationist sanctions and constructive engagement - at least provides the possibility of some room for diplomatic maneuvering at the national level, the approach would require a coordinated effort on the part of the U.S., E.U., and Japan. ${ }^{29}$ At the local level, a policy of "selective engagement" or better targeting of aid that promotes the growth of civil society is also a reasonable objective. ${ }^{30}$ Caution is warranted, however, as safeguards to ensure the transparency and accountability of foreign capital inflows are still lacking. According to MacLean, a resurgence of nepotism and corruption accompanying foreign aid without safeguards could lead to the monopolization of goods and services, giving non-state actors political legitimacy within ethnically, linguistically, and religiously divided nation states, and thus contributing to state fragmentation in Burma. ${ }^{31}$

\section{Change from Within?}

Perhaps the most worrisome threat to the generals concerning preservation of their regime can be described as internally generated when those sharing power fall into factional conflict. Callahan believes that internal military dilemmas arising from the Tatmadaw's state-building projects in the 1990s are probably

28. Stephen McCarthy, "Ten Years of Chaos in Burma: Foreign Investment and Economic Liberalization under the SLORC-SPDC, 1988-1998," Pacific Affairs 73:2 (Summer 2000), pp. 233-62.

29. See Joshua Kurlantzick, "Can Burma Reform?" Foreign Affairs 81:6 (November-December 2002), pp. 134-35; and Wayne Bert, "Burma, China, and the U.S.A," Pacific Affairs 77:2 (Summer 2004), p. 279.

30. Ashley South, "Political Transition in Myanmar: A New Model for Democratization," Contemporary Southeast Asia 26:2 (2004), p. 254.

31. Ken MacLean, "Reconfiguring the Debate on Engagement: Burmese Exiles and the Changing Politics of Aid," Critical Asian Studies 36:3 (2004), pp. 342-43. 
as much of a factor in the military's unyielding behavior as are military concerns about the NLD. The two primary internal concerns are the appearance of a generation gap and an experience gap in the officer corps and the tensions between Rangoon and regional warlord commanders. Discipline and morale are also low, reflecting the standards of mass recruitment; private ethnic or drug armies, which retained their arms following cease-fire agreements, show little respect for authority. ${ }^{32}$ Evidence of the generals' concern for maintaining discipline within their ranks can be gleaned from their occasional rotation of field commanders and the purging of senior SPDC members at various times since $1988 .^{33}$

Marginalization of the military's political leaders is not uncommonly practiced among the generals, and their treatment of General Aung San, Suu Kyi's father, is a case in point. Because of Aung San's assassination in 1947 aged only 32, Burma lacked a living political figure around whom people could rally in times of trouble. Most Burmese political elites have tried to draw from Aung San's legacy as a nationalist and independence fighter to legitimize their own aspirations to rule. Yet, Suu Kyi's presence has forced the generals to marginalize Aung San: whereas in the past the martyred leader had featured prominently during the Tatmadaw's commemorative ceremonies, including Armed Forces Day, he is no longer paid the same respect and his face no longer appears on the country's currency.

Perhaps more important in terms of consolidating the military's power and independence in recent years was the leadership's decision to distance itself from Ne Win and his daughter, Sandar. While there had been signs of this occurring, none were more revealing than the alleged failed coup attempt by $\mathrm{Ne}$ Win's three grandsons and son-in-law in March 2002. The plotters supposedly planned to coerce military commanders to kidnap the three top generals on Armed Forces Day, then take them to Ne Win so he could reorganize the junta and have them swear their allegiance. Ne Win denied knowledge of the coup; some observers saw it as a complete fabrication by the generals. Nonetheless, both Ne Win and Sandar were placed under house arrest, the national police chief was dismissed, and the 83 officers and soldiers assigned to guard Ne Win were sentenced by a military tribunal to 15 years' imprisonment. According to Maung Maung Gyi, under the rule of Burmese kings offenses against the king, whether trivial criticism or a serious conspiracy to topple the throne, were punishable by death. "Moreover," Maung Maung Gyi adds, "if a person

32. Callahan, "Burma," pp. 426-27.

33. This was most noticeably observed at the inception of the SPDC in 1997, yet perhaps also at the death of the hardliner and main rival to Khin Nyunt, Secretary-2 Tin Oo, along with several senior officers in a helicopter crash in February 2001. In November that year, Secretary-3 Win Myint along with Deputy Prime Minister Tin Hla and five other senior officers were sacked. 
were declared implicated in treason [which was] a usual charge for doing away with someone unwanted, his or her innocent relatives would be declared abettors and ordered to suffer the same fate. ${ }^{.34} \mathrm{Ne}$ Win's four relatives were found guilty of treason and sentenced to death by hanging in September 2002, after which their sentences were appealed twice and their appeals rejected both times. Incarcerated in Insein Prison, their only recourse was to await a likely pardon from Than Shwe and the commuting of their sentences to life imprisonment. Ne Win's death while under house arrest in December 2002 passed without ceremony or public mention.

In August 2003, following the events since Suu Kyi's arrest that May, the generals undertook a major reshuffling of cabinet positions. While Senior General Than Shwe remained head of state, chairman of the SPDC, and commander-in-chief of the armed forces, he made way for the more moderate - or at least less isolationist - Khin Nyunt to become prime minister. The move may have been undertaken in recognition of Khin Nyunt's superior ability to handle the international media and foreign diplomats on matters concerning Suu Kyi. However, the promotion of hardline Lieutenant General Soe Win to the position of Secretary-2 of the SPDC in February and to Secretary-1 following the cabinet reshuffle, as well as the naming of Shwe Mann as joint chief of staff in 2002, possibly to replace Maung Aye in the future, meant that Khin Nyunt would have to share power with Soe Win and Shwe Mann. Khin Nyunt's position as prime minister, therefore, was largely ceremonial as long as the ruling council existed in its current form; if he lost his role as director of military intelligence Khin Nyunt would have become a general without an army. In October 2004, he was charged with corruption-a common justification during a purge - and placed under house arrest along with officers loyal to him. His intelligence apparatus was disbanded and he was replaced by Than Shwe's protégé, Soe Win. It may take the passing of the current generation of generals before factions within the Tatmadaw are allowed to thrive.

\section{Power, Institutions, and Trust}

Reforming a regime is no lesser a task than instituting one: part of the reason for this is that the people must be open to change. Over 40 forty years of autarchic military rule in Burma has made the people politically apathetic, fearful of reprisals, distrustful of the military-run institutions, yet deeply wary of foreign influence and Western models of society. In 1996, Lee Kuan Yew correctly observed that there was only one effective instrument of government in Burma-the army. ${ }^{35}$ The army remains the dominant institution in Burma

34. Maung Maung Gyi, Burmese Political Values (New York: Praeger, 1983), p. 24.

35. Lee Kuan Yew, Straits Times, June 12, 1996; and the New Light of Myanmar, June 15, 1996. 
today and, as Robert Taylor says, "its grip over the media, the educational system and the bureaucracy is as firm as that of its predecessors." 36 Some commentators have asserted that the Burmese election results in 1990 merely demonstrated mass rejection of the autarchic economic policies of the previous 26 years and that the continuation of military rule while a constitution is being written would actually be a blessing for the civilian government that will follow. These observers argue that a civilian government would have a better chance of coping with the results of economic reform once the worst consequences of structural adjustment are over. ${ }^{37}$ Their faith in economic rationalism, it seems, has been trumped by the Tatmadaw's lust for power.

Such arguments reflect the empirical deficiencies of utilizing the political economy approach to analyze a country like Burma. But analysts who adopt a purely institutionalist perspective to criticize the prospects for reform can produce equally stunted conclusions. The latter may fear that liberal democratic institutions and a market economy may not be in the people's best interest, but it would also be prudent to note that black-market trade is what currently prevents the total collapse of the Burmese economy. Nevertheless, to currently impose a Western-style democratic political system upon Burma could jeopardize the people's well-being simply because the army has been the dominant institution since 1962, when officers began ruling like kings, effectively concentrating all executive, legislative, and judicial powers in themselves. ${ }^{38}$ Yet, existing regimes can be assisted by opening the door to the possibility that reforms may lead to what is best, most attainable, and most fitting for the society. In other words, a better mixing of the oligarchic and democratic elements within the Burmese regime can still occur within the limits imposed by the country's severe institutional and infrastructural deficiencies. To relinquish this possibility in order to preserve the status quo invites justifiable criticism because in Burma the defining principal wishes of tyrants - that the ruled have only modest thoughts, that they distrust one another, and that they are incapable of activity - are fulfilled under the rule of the Tatmadaw. ${ }^{39}$

\section{A Question of Trust}

It could be argued that making the people poor and keeping them too busy to make trouble has had less to do with deliberate actions on the part of the generals than their own general ineptitude. It could also be argued that these

36. Robert Taylor, ed., Burma: Political Economy under Military Rule (New York: Palgrave, 2001), p. 13.

37. Robert Taylor, "Burmese Army and the 'National Interest'," Bangkok Post, June 16, 1990; and Working People's Daily (Rangoon), June 20, 1990, p. 7.

38. Maung Maung Gyi, Burmese Political Values, pp. 34-35.

39. Lord, trans., Aristotle, The Politics, pp. 1314a15-26. 
military leaders took no genuine steps to rectify the economic situation but in fact actively abetted immiseration by using forced labor for various archaeological, religious, and economic projects. The people themselves harbor strong memories of the military's suppression of democracy demonstrators and may now be too impoverished to challenge the SPDC. It appears that political trust is an attribute currently lacking in Burmese society. Indeed, Lucian Pye believes that Burma suffers from acute problems with social capital because basic distrust is so widespread that inferiors cannot trust anyone with power; he argues that this goes back to Burmese socialization practices that exist to this day. ${ }^{40}$ Because of this, the Burmese find it "difficult to conceive of themselves in any way associated with objective and regulated systems of human relationships." 41 Samuel Huntington believes that because "the presence of distrust in these societies limits individual loyalties to groups that are intimate and familiar ... people are and can be loyal to their clans, perhaps to their tribes, but not to broader political institutions." 42 According to Pye, Burmese culture above all evinces a deep ambivalence about power. Any Burmese quest for power, or perhaps even high thoughts, would be restrained by a higher sense of civility that ensures social order. Yet, civility, he says, is only the first step toward the development of social capital and civil society. And because the Burmese show little or no trust, their development of social capital has not gone far beyond the realm of civility. ${ }^{43}$

One of the greatest challenges to be faced in reforming the Burmese regime, therefore, is not necessarily the absence of democratic political institutions as such but the people's trust in any political institutions at all. More than four decades of military rule have only reinforced what Lucian Pye and Maung Maung Gyi discovered and what Mikael Gravers notes: "[T]he traditional Burman concepts pertaining to power as personal attributes, rather than attributes of systems, have been retained since independence. . . . Power in Burma is not merely concentrated within institutions, it is also highly concentrated around a few persons." ${ }^{4}$ Applying political and economic institutional analysis per se ignores the complex array of mores that guide social relationships in Burma. As the case of East Timor shows, addressing infrastructural shortfalls may be

40. Lucian Pye, "Civility, Social Capital, and Civil Society: Three Powerful Concepts for Explaining Asia," in Patterns of Social Capital, Stability, and Change in Historical Perspective, Robert Rotberg, ed. (New York: Cambridge University Press, 2001), pp. 386-87.

41. Lucian Pye, Politics, Personality, and Nation Building: Burma's Search for Identity (New Haven: Yale University Press, 1962), pp. 203, 292.

42. Samuel Huntington, Political Order in Changing Societies (New Haven: Yale University Press, 1968), pp. 29-30.

43. Pye, "Civility, Social Capital, and Civil Society," pp. 386-87.

44. Mikael Gravers, Nationalism as Political Paranoia in Burma (London: Curzon Press, 1999), pp. 69, 134. 
attempted with international funding. However, Suu Kyi notes that if liberal democracy - along with the basic institutions and practices that make for good governance-were to be established in Burma (let alone whether they are appropriate) this would not provide a panacea for all of the country's ills. ${ }^{45}$ What most threatens a successful transition from the status quo in Burma is the respect paid to (personal) power, which has only been magnified by the Tatmadaw's running of all political and economic institutions for so long.

What passes as patron-client ties in one person's thinking may constitute nepotism in another, and at least at present bribes and blood ties may resonate more effectively for the average Burmese citizen than trusting in vague ideas about the merits of democratic institutions and the doctrine of the separation of powers. Yet, patron-client ties that are backed by brute force can only intimidate the ruled and reinforce one of the chief desires of a tyrant, that the ruled have only modest thoughts, because a small-souled person will not conspire against anyone. ${ }^{46}$ A long history of political opposition in Burma would suggest that spiritedness is not a personal attribute that can be easily destroyed. Nor are the Burmese people particularly comfortable with enslavement. Spiritedness may, however, be suppressed, inciting people who cannot freely voice or act out their opposition to turn instead toward what James Scott calls "everyday forms of peasant resistance." 47 The Tatmadaw has attempted to suppress Burmese spiritedness with impoverishment, Draconian laws, fear, threats, and political rhetoric that allows any official act to be justified on the grounds of national survival, thus fostering a communal paranoia about foreign influence. While the Tatmadaw's military power promises to inform its political agenda, its political rhetoric will only succeed by maintaining the public's ignorance. This provides one key to any possibility of reform.

The brutish mode of tyranny adopted by the regime aims at making the ruled distrust one another, and tyranny cannot be overthrown until some persons are able to trust each other. A tyrant makes everyone as ignorant of one another as possible because mutual knowledge tends to create trust. Francis Fukuyama believes that social capital is often produced by hierarchical sources of authority, including Buddhism, whose norms are "transmitted from one generation to the next through a process of socialization that involves much more habit than reason." 48 But Pye's analysis of Burmese social capital

45. Suu Kyi, "Commencement Address."

46. Lord, trans., Aristotle, The Politics, pp. 1314a16-17.

47. See James Scott, Weapons of the Weak: Everyday Forms of Peasant Resistance (New Haven: Yale University Press, 1985); James Scott, Domination and the Arts of Resistance: Hidden Transcripts (New Haven: Yale University Press, 1990); and Janet Philp and David Mercer, "Politicized Pagodas and Veiled Resistance: Contested Urban Space in Burma," Urban Studies 39:9 (2002), pp. 1587-1610.

48. Francis Fukuyama, "Social Capital, Civil Society, and Development," Third World Quarterly 22:1 (2001), p. 16. 
suggests that it is socialization practices that reinforce the public's negative perceptions of power and trust. Addressing the problem of trust, therefore, is not a simple task, yet it may not be impossible. Indeed, it has been argued that following the ceasefires among ethnic insurgents over the past decade, civil society networks - primarily those that are religious or oriented to community development-have reemerged within and among ethnic nationality communities. This phenomenon has been largely ignored because of the focus on elitelevel politics and the U.N.-brokered peace talks. Although the most substantial constraint on the growth of civil society in Burma is "government distrust," according to South, the past five to 10 years have seen a partial readjustment of state-society relations that is also reflected in the leadership's need to reach some consensus-based position leading up to the National Convention. ${ }^{49}$

Yet, democratic civil society also requires the rule of law and strong institutions in order to flourish. It may be reasonable to argue for a "bottom up" approach to supplement any possible "top down" impetus for democratic reforms instigated by the elites. But if the latter impetus appears to be withheld indefinitely, this may also shape the character of the former-unless the minorities already consider themselves totally independent of mainstream Burmese civil society. The average Burmese citizen may have little trust in the political and economic institutions of the government, ${ }^{50}$ in rules and regulations that can change on a whim, and in their Peace and Development Council representatives, at least at the higher division and township levels. Nonetheless, the same may not be true for their various informal social and religious organizations. Naturally, one would also expect that the people's highest levels of trust would be directed toward their immediate family, friends, and neighbors, rather than to the majority of their fellow citizens. It is difficult to see how fostering a change in the levels of trust people have in the system could occur without reforming the rule of law as it currently operates; still, social and religious organizations - at least those that have not been monopolized by the militarymay play an important role in fostering the local norms required to sustain any just reforms introduced at the elite level.

Studies of political rhetoric reveal that common opinions on a subject may be coerced by politicians whose rhetoric is pitched toward a particular end.

49. Ashley South, "Political Transition in Myanmar: A New Model for Democratization," p. 253. An analogy could be made here to the "civil society" forged along the lines of the "spirit of Panglong" at the Panglong conference in 1947.

50. This situation will likely deteriorate further following Than Shwe's decision to relocate the administrative capital away from the population to the newly founded, heavily fortified jungle compound called Naypyidaw, near remote Pyinmana, 400 kilometers north of Rangoon. One possible reason for the move is to prevent a collapse of government administration should the mass demonstrations of 1988 reoccur in Rangoon. See Aung Zaw, "Retreat to the Jungle," Irrawaddy Online Edition, December 2005. 
The goal of both the Tatmadaw and the opposition is preservation of the regime, either by maintaining stability through order or by improving stability through change. Because trust is lacking in the formal institutions of governance, at least among the Burman majority, political reformers must produce the right kind of rhetoric to amend this state of affairs. Common sense suggests that this means appealing to the social institutions that the Burman people most trust: Buddhism and the Sangha (community of monks). ${ }^{51}$ This is why Suu Kyi has presented her democratic political ideas, as often as possible, via the medium of Buddhist language and symbolism when addressing the majority Burman population. Suu Kyi calls the Burmese struggle for democracy a "spiritual revolution" not only because unjust regulations make it impossible for it to be a political and social revolution but also because mistrust is so widespread that the people must be convinced of the need for political change. This also requires a change in the values they previously lived by. A revolution of the spirit requires the development of new norms based on a combination of traditional Buddhist values and modern political principles. ${ }^{52}$ The people's perception of foreign ideas and models of government must also be addressed; this is what Suu Kyi has attempted to do.

Indeed, reforming the regime appears no less difficult a task than establishing a regime from the outset. It may on the surface appear drastic to suggest that the people must modify their extant norms, mores, and socialization processes. Still, countless historical examples suggest that education and habituation to a new regime is possible and that some cultural traits, mores, and behavioral norms may not be as static as certain commentators claim. Perhaps the eruption of mass demonstrations in 1988 suggests not only that cultural traits may be relatively malleable but also that the Burmese do not fear anarchy more than tyranny.

Prudence assists the political expert in discussing what laws are best and most fitting for reforming existing regimes. The wholesale application of American-style democracy, for example, may not be most fitting for Burma. Because a regime comprises not only the arrangement and distribution of offices and the establishment of authority but also the ends pursued, it is important for political reformers to concentrate on the aims of reform before advocating adoption of specific institutions. Given the differences between American and Burmese mores, it would not have been fitting for Suu Kyi to simply replicate the political rhetoric of Publius in The Federalist papers. $^{53}$

51. Because over $80 \%$ of Burmese are Buddhist, the dialogue of political opposition in Burma has traditionally been couched in Buddhist terms, often seeking the support of the Sangha to gain moral legitimacy.

52. Suu Kyi, The Voice of Hope, pp. 74-76.

53. E.g., Alexander Hamilton, James Madison, and John Jay, in Jacob E. Cooke, ed., The Federalist (Middletown, Conn.: Wesleyan University Press, 1961). 
Her political rhetoric presented the new regime's ends in terms of Burmese culture for her message to be favorably received. This message included, for example, a basic respect for human rights. While the generals claim to respect the Universal Declaration of Human Rights, they state that the Eastern concept of human rights is not the same as the Western concept and that respect for the individual should never take precedence over society's needs. Suu Kyi, however, asserts that democracy is based on respect for the individual; some observers feel that based on her reliance on Buddhism in her writings, she is suggesting that the Buddhist concept of the Middle Way helps avoid the extremes of individualism and collectivism.

The generals' ends, on the other hand, revolve around power: these officers play a constant game of balancing competing interests and claims against each other. Apart from fostering closer ties in recent years with the Chinese, Indians, and certain ASEAN member states - primarily in order to acquire arms, replenish foreign reserves, and build regional moral legitimacy - the conduct of the generals reflects Burma's foreign policy since independence: neutralism, or positively or negatively aligned non-action. Their economic policies remain shortsighted, along with their social, domestic, and foreign policies. Maintaining the preservation of the Tatmadaw's political power is perhaps the only constant running through the SPDC's arguments for legitimacy; any policy, action, or institution that can be manipulated to keep the generals in power will be used to do so.

\section{Prospects for Political Reform}

It is important that statesmen and policymakers alike understand the national character of a regime and the character traits of the people that make it up. Hoping that democracy takes root in certain deviant regimes merely through the application of democratic institutions, without addressing the political and economic circumstances or cultural beliefs of the people, may prove fruitless. At times, the power of tyrants appears to be as lasting as the cultural traits of those they rule, yet neither is inevitable or unchanging.

That personal power is respected more in Burma than power embodied in various institutions of governance suggests that a transformation toward a more just regime would require a great deal of time and education. The Burmese cannot trust in their political institutions until they trust each other: just as ignorance maintains a tyranny, education is required to overcome one. The basic social fabric in Burma, the norms, mores, and nature of trust, must be addressed before attempting to introduce the political and economic institutions of a liberal democracy because these questions will shape the character and functioning of the institutions themselves. And when these institutions are discussed, perhaps it would be more sensible not to dismiss them as Western and hence inappropriate but to frame the discussion within the guidelines of 
flexibility and prudence. Statesmen should introduce the topic of universal ideas while taking into account the particular circumstances, the condition of trust, and the cultural beliefs of the people. Because knowledge creates trust, education to improve justice under the regime should be of prime importance. Even earlier, people should be alerted to the true nature of their rulers' political rhetoric.

Despite their public displays of piety in recent years, Burma's generals have been unable to enhance their moral or political legitimacy. Their lack of unquestioned authority requires that they be more oppressive (and therefore unstable), enabling them to maintain power against the wishes of the people. The hopes of any faction-led changes arising from within the military would seem for now to have been nipped in the bud upon Khin Nyunt's late 2004 "early retirement" and replacement. The hardliners have firmed up their base and now the "democratic process" lies solely in their hands and in how they choose to define it; much will depend on whether power alone satisfies the generals and how importantly they regard international legitimacy.

Ultimately, any lasting improvements in justice and stability in Burma would require not only the successful resolution and securing of political arrangements for ethnic minorities but also a partial power shift from the army to the people, a move that would antagonize the army without giving the generals any guarantee of popular support. Such a shift occurred when the Marcos regime was deposed in the Philippines in 1986, but the Burmese two years later lacked the requisite social group organization, an independent middle class, and the hierarchical equivalent of the Catholic Church. And although the IMF created the circumstances leading to President Suharto's 1998 departure from office in Indonesia, Burma has already been ostracized from international funding and cannot as easily be pressured. Further, and unlike both these cases, the Tatmadaw generals - like the Chinese People's Liberation Army in 1989 — did in fact open fire on their own people. Huntington believes that the better course for new democracies dealing with the crimes of former authoritarian rulers is to adopt the least satisfactory alternative: "do not prosecute, do not punish, do not forgive, and, above all, do not forget." ${ }^{\text {4 }}$ For a shift in power from army to citizens to be at least possible, Suu Kyi has had to guarantee that she would not hunt down the generals if power were ever to change hands. She believes it should suffice that the people be told the truth.

So long as the people see the generals, and not Ne Win alone, as being most responsible for Burma's acts of tyranny, confidence building may be all that the current leadership, especially the hardliners in charge, is prepared to

54. Samuel Huntington, The Third Wave: Democratization in the Late Twentieth Century (Norman: University of Oklahoma Press, 1991), p. 231; and Samuel Huntington, "Reforming CivilMilitary Relations," Journal of Democracy 6:4 (October 1995), pp. 15-16. 
commit to in any dialogue with the NLD and ethnic minorities. Although a shift of the generals' power to the people is not absolutely impossible, it would seem that its safe actualization is highly improbable in the current circumstances. The generals cannot shift power without intimidating their own middle class (the Tatmadaw), nor would they sensibly wish to create the circumstances that could, in all probability, lead to their own downfall. For those reasons, improvements in stability and justice in Burma are unlikely to eventuate any time soon. Such lasting change would require circumstances that are beyond the generals' creation and control. 